\title{
RESEARCH
}

Open Access

\section{Incidence, casualties and risk characteristics of civilian explosion blast injury in China: 2000-2017 data from the state Administration of Work Safety}

Xu Wang ${ }^{1,2 \dagger}$, Juan Du ${ }^{1 \dagger}$, Zhuo Zhuang ${ }^{3}$, Zheng-Guo Wang ${ }^{1}$, Jian-Xin Jiang ${ }^{1 *}$ and Ce Yang ${ }^{1 *}$

\begin{abstract}
Background: Civilian explosion blast injury is more frequent in developing countries, including China. However, the incidence, casualties, and characteristics of such incidents in China are unknown.

Methods: This is a retrospective analysis of the State Administration of Work Safety database. Incidents during a period from January 1, 2000 to April 30, 2017 were included in the analysis. The explosions were classified based on the number of deaths into extraordinarily major, major, serious and ordinary type. Descriptive statistics was used to analyze the incidence and characteristics of the explosions. Correlation analysis was performed to examine the potential correlations among various variables.

Results: Data base search identified a total of 2098 explosions from 2000 to 2017, with 29,579 casualties: 15,788 deaths (53.4\%), 12,637 injured (42.7\%) and 1154 missing (3.9\%). Majority of the explosions were serious type (65.4\%). The number of deaths (39.5\%) was also highest with the serious type $(P=0.006)$. The highest incidence was observed in the fourth quarter of the year (October to December), and at 9:00-11:00 am and 4:00-6:00 pm of the day. The explosions were most frequent in coal-producing provinces (Guizhou and Shanxi Province). Coal mine gas explosions resulted majority of the deaths $(9620,60.9 \%)$. The number of explosion accidents closely correlated with economic output (regional economy and national GDP growth rate) ( $r=-0.372, P=0.040 ; r=0.629, P=0.028)$.
\end{abstract}

Conclusions: The incidence and civilian casualties due to explosions remain unacceptabe in developing China. Measures that mitigate the risk factors are of urgently required.

Keywords: Explosion, Blast exposure, Blast mitigation, Overpressure, trauma and injury

\footnotetext{
* Correspondence: hellojjx@126.com; sepsismd@126.com

${ }^{\dagger}$ Xu Wang and Juan Du contributed equally to this work.

'State Key Laboratory of Trauma, Burn and Combined Injury, Research

Institute of Surgery, Daping Hospital, Army Medical University, Chongqing 400042, China

Full list of author information is available at the end of the article
}

(c) The Author(s). 2020 Open Access This article is licensed under a Creative Commons Attribution 4.0 International License, which permits use, sharing, adaptation, distribution and reproduction in any medium or format, as long as you give appropriate credit to the original author(s) and the source, provide a link to the Creative Commons licence, and indicate if changes were made. The images or other third party material in this article are included in the article's Creative Commons licence, unless indicated otherwise in a credit line to the material. If material is not included in the article's Creative Commons licence and your intended use is not permitted by statutory regulation or exceeds the permitted use, you will need to obtain permission directly from the copyright holder. To view a copy of this licence, visit http://creativecommons.org/licenses/by/4.0/. The Creative Commons Public Domain Dedication waiver (http://creativecommons.org/publicdomain/zero/1.0/) applies to the data made available in this article, unless otherwise stated in a credit line to the data. 


\section{Background}

The various risks in daily production determine the longterm likelihood of explosives accidents [1, 2]. In particular, recent giant explosives accidents (e.g., "8.12" giant explosion in Tianjin harbor and "8.2" Kunshan explosion in Jiangsu) emphasized the urgent need for prompt action [3, 4]. A major obstacle in designing and implementing effective measures to curb such incidents and emergency responses is the lack of basic information, including the incidence, the type, and risk factors $[5,6]$.

In civilian explosions, blast injuries are generally categorized as primary, secondary, tertiary and quaternary types [7, 8]. Civilian explosive blasts often occur in closed or semi-closed spaces. Primary blast injuries may be amplified by wave reflection and superposition from the surrounding walls rather $[2,5,7,8]$. Tympanic membranes, lungs, intestinal ducts and the brain are the most frequently injured organs among survivors [9-14]. Secondary blast injuries are caused by flying debris $[15,16]$. Tertiary blast injuries occur when a victim is physically displaced by the force of air movement or is crushed by structural collapse, often in dilapidated buildings such as factories, folk houses and underground shafts [3, 17]. Quaternary blast injuries mainly include burns and inhalational injury, and are often seen in explosions caused by chemical compounds or petroleum [2, 3, 18]. In compared to soldiers in combat, civilians often lack training and personal protective equipment, and thus are prone to more severe injuries [19-21].

Existing literature recognizes the influence of economic development on traffic accidents [22, 23]. However, whether civilian explosives accidents are associated with economic development is unknown. In the present study aims, we conducted a retrospective analysis of the State Administration of Work Safety (SAWS) database, and systematically examined the profiles of civilian explosive blast injuries after 2000.

\section{Methods}

\section{Data collection}

The State Administration of Work Safety (SAWS) is a nation-wide database of civilian casualties caused by explosions (http://www.chinasafety.gov.cn/newpage) in China. Reporting to SAWS is mandatory. The SAWS database was searched for casualty records of all casualties caused by explosions between January 1, 2000 and April 30, 2017 using "explosions", "low speed detonation" and "deflagration" as the search terms. Terrorism-related events were not included. Reports published by government-sponsored websites (Xinhua News Agency, China News Service, China Daily, People's Daily) were reviewed to verify the accuracy and completeness of the data retrieved from the SAWS database. We also searched PubMed, Web of Science and ProQuest databases for possible missing accidents using the search terms "explosive", "explosion", "blast" and "overpressure" to further verify the integrity of the data from the SAWS database.

National population, gross domestic product (GDP) and GDP per capita were collected from the National Bureau of Statistics of the People's Republic of China. This manuscript was drafted in compliance with the Strengthening the Reporting of Observational Studies in Epidemiology (STROBE) statement.

\section{Ethical approval}

This study was approved by the Institutional Review Board and the Medical Ethics Committee of Daping Hospital, the Army Medical University, China (HUUWEC2017017).

\section{Data analysis}

Annual incidence of explosion casualties, including death, injured, injury severity and missing, was calculated. The trend was analyzed by correlation analysis based on incident year. The explosion was graded based on the number of deaths into: ordinary $(n<3)$, serious $(3 \leq n<10)$, major $(10 \leq n<30)$ or extraordinarily major $(n>30)$. To determine whether the explosion blast injury follow a temporal pattern, a Pearson correlation analysis was performed between the numbers of explosions and the timing (quarter, month, day and time).

\section{Statistical analysis}

All statistical analyses were conducted using SPSS 24.0 for Windows (Shareware 1050, IBM, USA). Categorical variables, presented as numbers and percentage, were analyzed with Chi-Square tests. Correlation analysis was performed to examine the potential correlations among continuous variables. Descriptive statistical methods were used to analyze the grade and type of explosion, explosion charges, and geographical location. $P<0.05$ (2-sided) were considered significant.

\section{Results}

\section{Incidence of explosions and casualties}

A total of 2098 explosion accidents were identified in the SAWS database during a period from January 1, 2000 and April 30, 2017. The total casualty was 29,579: 15,788 deaths (53.4\%), 6130 severe injuries (20.7\%), 6507 minor injuries $(22.0 \%)$, and 1154 missing (3.9\%). Pearson correlation analysis revealed a positive correlation between the total number of explosion accidents with the number of deaths $(r=0.881, P=0.0004$, Table 1 , Fig. $1 \mathrm{a})$. The 2004/2005 years had the highest number of accidents and deaths. There was a general tendency for decreasing incidence of explosion blast injury as well as death per million people after 2001. 
Table 1 Incidence and casualties by year

\begin{tabular}{|c|c|c|c|c|c|c|c|c|}
\hline Year & $\begin{array}{l}\text { Total accidents } \\
(n=2098)[n(\%)]\end{array}$ & $\begin{array}{l}\text { Total casualty } \\
(n=29,579)[n(\%)]\end{array}$ & $\begin{array}{l}\text { Injured } \\
(n=12,637) \\
{[n(\%)]}\end{array}$ & $\begin{array}{l}\text { Deaths } \\
(n=15,788) \\
{[n(\%)]} \\
\end{array}$ & $\begin{array}{l}\text { Missing } \\
(n=1154) \\
{[n(\%)]} \\
\end{array}$ & Total population(/107) & $\begin{array}{l}\text { Incidence of blast } \\
\text { injury per million } \\
\text { people }\end{array}$ & $\begin{array}{l}\text { Death rate per } \\
\text { million people }\end{array}$ \\
\hline $2017^{a}$ & $11(0.5)$ & $86(0.3)$ & $35(0.3)$ & $48(0.3)$ & $3(0.3)$ & - & - & - \\
\hline 2016 & $41(2.0)$ & $576(1.9)$ & $260(2.1)$ & $306(1.9)$ & $10(0.9)$ & 139.0 & 0.29 & 2.20 \\
\hline 2015 & $38(1.8)$ & 1878(6.3) & 1502(11.9) & $362(2.3)$ & $14(1.2)$ & 137.5 & 0.28 & 2.63 \\
\hline 2014 & $61(2.9)$ & 1443(4.9) & $915(7.2)$ & $523(3.3)$ & $5(0.4)$ & 136.8 & 0.45 & 3.82 \\
\hline 2013 & $74(3.5)$ & $1490(5.0)$ & $805(6.4)$ & $671(4.3)$ & $14(1.2)$ & 136.1 & 0.54 & 4.93 \\
\hline 2012 & $63(3.0)$ & 1019(3.4) & $539(4.3)$ & $467(3.0)$ & $13(1.1)$ & 135.4 & 0.47 & 3.45 \\
\hline 2011 & $107(5.1)$ & $1241(4.2)$ & $686(5.4)$ & $515(3.3)$ & $40(3.5)$ & 134.8 & 0.79 & 3.82 \\
\hline 2010 & $135(6.4)$ & $1981(6.7)$ & 1182(9.4) & $756(4.8)$ & $43(3.7)$ & 134.1 & 1.01 & 5.64 \\
\hline 2009 & $115(5.5)$ & $1480(5.0)$ & $700(5.5)$ & $744(4.7)$ & $36(3.1)$ & 133.5 & 0.86 & 5.57 \\
\hline 2008 & $87(4.1)$ & 1049(3.5) & $464(3.7)$ & $559(3.5)$ & $26(2.3)$ & 132.8 & 0.66 & 4.21 \\
\hline 2007 & $118(5.6)$ & $1381(4.7)$ & $507(4.0)$ & $804(5.1)$ & $70(6.1)$ & 132.1 & 0.89 & 6.09 \\
\hline 2006 & $147(7.0)$ & 1979(6.7) & $747(5.9)$ & $1173(7.4)$ & $59(5.1)$ & 131.5 & 1.12 & 8.92 \\
\hline 2005 & $168(8.0)$ & 2701(9.1) & $814(6.4)$ & 1824(11.6) & $63(5.5)$ & 130.8 & 1.28 & 13.94 \\
\hline 2004 & $193(9.2)$ & $2275(7.7)$ & $741(5.9)$ & $1421(9.0)$ & 113(9.8) & 130.0 & 1.48 & 10.93 \\
\hline 2003 & 219(10.4) & 2390(8.1) & $906(7.2)$ & 1382(8.8) & 102(8.8) & 129.2 & 1.70 & 10.70 \\
\hline 2002 & $211(10.1)$ & $2051(6.9)$ & $512(4.1)$ & $1421(9.0)$ & $118(10.2)$ & 128.5 & 1.64 & 11.06 \\
\hline 2001 & $201(9.6)$ & $2171(7.3)$ & $535(4.2)$ & 1407(8.9) & 229(19.8) & 127.6 & 1.58 & 11.03 \\
\hline 2000 & $109(5.2)$ & $2388(8.1)$ & 787 (6.2) & 1405(8.9) & 196(17.0) & 126.7 & 0.86 & 11.09 \\
\hline
\end{tabular}

"The incidence of blast injury in millions of people $=$ Number of accidents $/$ Total population $\times 10^{6}$; ${ }^{\#}$ Death rate of millions of people $=$ Deaths $/$ Total population of China $\times 10^{6} ;{ }^{a}$ Only the first four months were included in $2017 ;$ "-". No data

\section{Explosion grade vs. casualties}

Among the 2098 explosions, the number of accidents was 79 for extraordinarily major accident (3.8\%), 283 for major accident (13.5\%), 1372 for serious accident (65.4\%) and 364 for ordinary accident (17.3\%), with the largest number in the serious category $(P=0.03)$. The mean number of casualties and deaths in the extraordinarily major accidents was 104.3 and 58.0 per accident, respectively, both highest among the four categories. There was no statistical difference between the number of severe and minor injuries. The number of missing was $3.8 \%$ of the total casualties, with the highest number in the ordinary category (S Table 1).

\section{Timing of the explosions}

The fourth quarter of the year (October - December) had the highest incidence of explosion accidents. With the day, the explosions were most frequent at 9:00-11:00 am and 4: 00-6:00 pm. Pearson correlation analysis showed a correlation between the number of accidents with the number of deaths by time interval $(r=0.857, P=0.006$, Fig. 1b). No temporal pattern was identified with regards to the day within a month or month within a year (Fig. 1c).

\section{Geographical distribution}

The highest incidence and deaths were identified in Guizhou Province in southwest China $(248,11.8 \%)$ and
Shanxi Province in northern China (2289, 14.6\%), respectively. Extraordinarily major accidents were most common in Shanxi $(26,32.9 \%)$, Henan $(8,10.1 \%)$ and Heilongjiang $(8,10.1 \%)$. Major accidents were also common in Shanxi $(41,14.5 \%)$, Guizhou $(39,13.8 \%)$ and Hunan (25, 8.8\%). Serious accidents were most frequent in Guizhou (165, 12.0\%) and Hunan (114, 8.3\%). Ordinary accidents were most common in Guizhou (42, $11.5 \%$ ) and Sichuan (38, 10.4\%) (Fig. 2). Pearson correlation analysis revealed a positive correlation between the number of accidents with the number of deaths by regions $(r=0.827, P=0.002)$.

\section{Causes of explosions and relationship with casualties}

The causes of explosions were categorized into seven types: coal mine gas, fireworks, blasting agent, chemical product, high-pressure equipment, flammable explosives and others. More than three quarters of the explosions resulted from coal mine gas $(1029,49.1 \%)$, fireworks (323, $15.4 \%)$ or flammable explosives $(260,12.4 \%$, Table 2$)$.

Among the various causes of explosions, coal mine gas explosions resulted in the highest casualties $(14,360$, 48.6\%): 9620 deaths (67.0\%) and 3832 injured (26.7\%). The percentage of severe injuries in explosions due to flammable explosives and high-pressure equipment was 45.1\% (1921) and 36.2\% (333), respectively. Furthermore, the explosion of coal mine gas $(212,85.0 \%)$ was mostly 

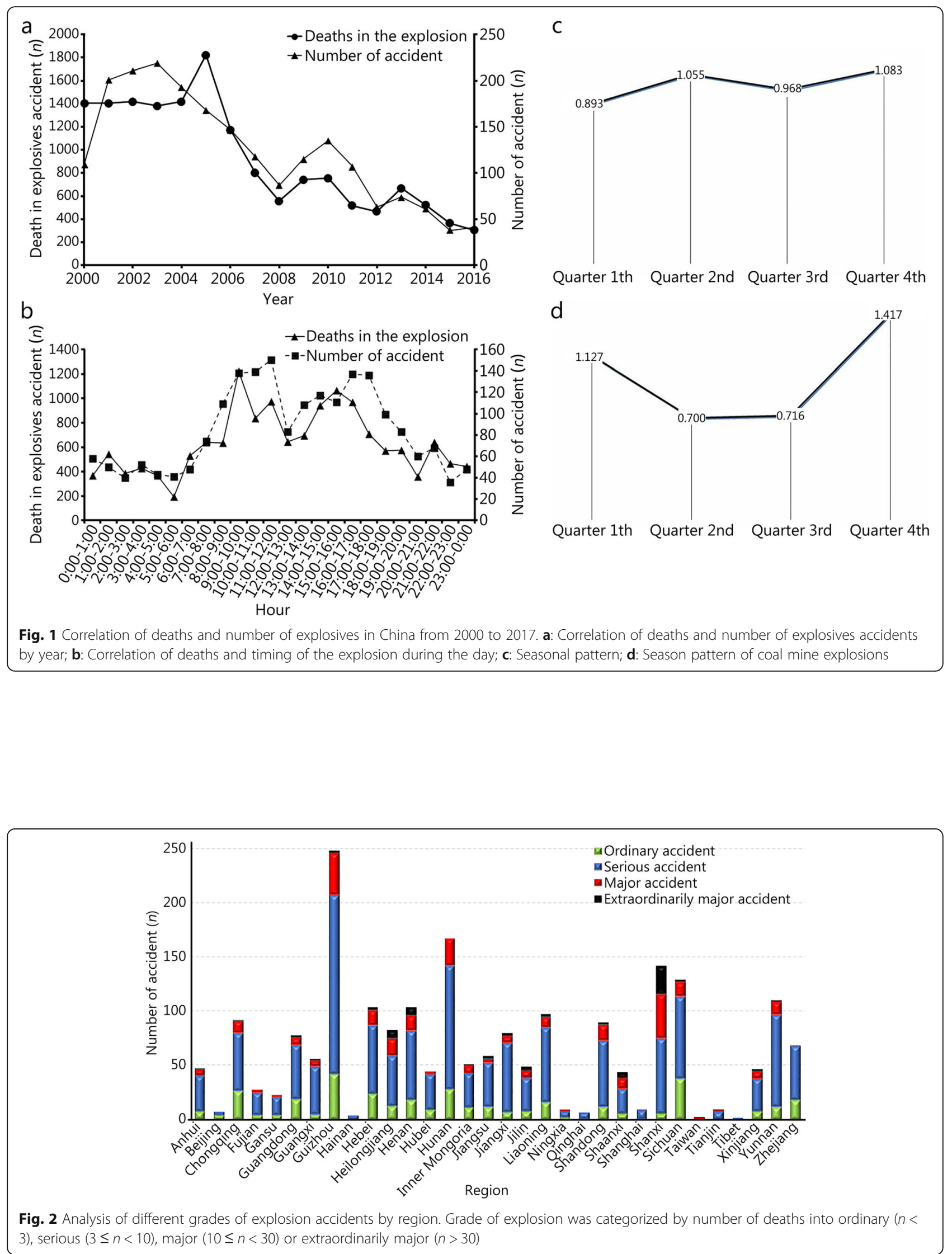
Table 2 Casualty breakdown by explosion types [ $n(\%)]$

\begin{tabular}{|c|c|c|c|c|c|c|}
\hline Explosive types & Number of accidents & Total casualty & Patients with severe injuries & Patients with minor injuries & Deaths & Missing \\
\hline Coal mine gas & $1029(49.0)$ & $14,360(48.5)$ & $1641(26.8)$ & 2191(33.7) & $9620(60.9)$ & $908(78.7$ \\
\hline Fireworks & $323(15.4)$ & $3945(13.3)$ & $907(14.8)$ & $1105(17.0)$ & 1857(11.8) & $76(6.6)$ \\
\hline Explosive blasting agent & $187(8.9)$ & 2970(10.0) & $683(11.1)$ & $937(14.4)$ & 1286(8.1) & $64(5.5)$ \\
\hline Chemical product & $158(7.5)$ & 2897(9.8) & $583(9.5)$ & 1280(19.7) & $992(6.3)$ & $42(3.6)$ \\
\hline High pressure equipment & $112(5.3)$ & $919(3.1)$ & $333(5.4)$ & $130(2.0)$ & $449(2.8)$ & $7(0.6)$ \\
\hline Flammable explosive & $260(12.4)$ & $4260(14.4)$ & $1921(31.3)$ & $816(12.5)$ & $1468(9.3)$ & $55(4.8)$ \\
\hline Other & $29(1.4)$ & $228(0.8)$ & $62(1.0)$ & $48(0.7)$ & $116(0.7)$ & $2(0.2)$ \\
\hline
\end{tabular}

seen among these regions. Coal mine gas explosions occurred more frequently in the second quarter of the year (April, May and June). Explosions due to fireworks were more frequent in the first and fourth quarters, and particularly in January and November (S Table 2, Fig. 1d).

\section{Explosion accidents vs. economic development}

Pearson correlation analysis indicated a correlation between the regional population and economy (regional economy and national GDP growth rate) with the number of accidents $(r=0.470, P=0.008$; $r=-0.372, P=0.040 ; r=0.629, P=0.028$, Fig. $3, \mathrm{~S}$ Table 2).

\section{Explosions and potential protection}

Coal mine gas explosions were the most frequent cause of the explosion accidents (126, 24.5\%). Seventy point $6 \%$ (363 cases) of the explosion charges

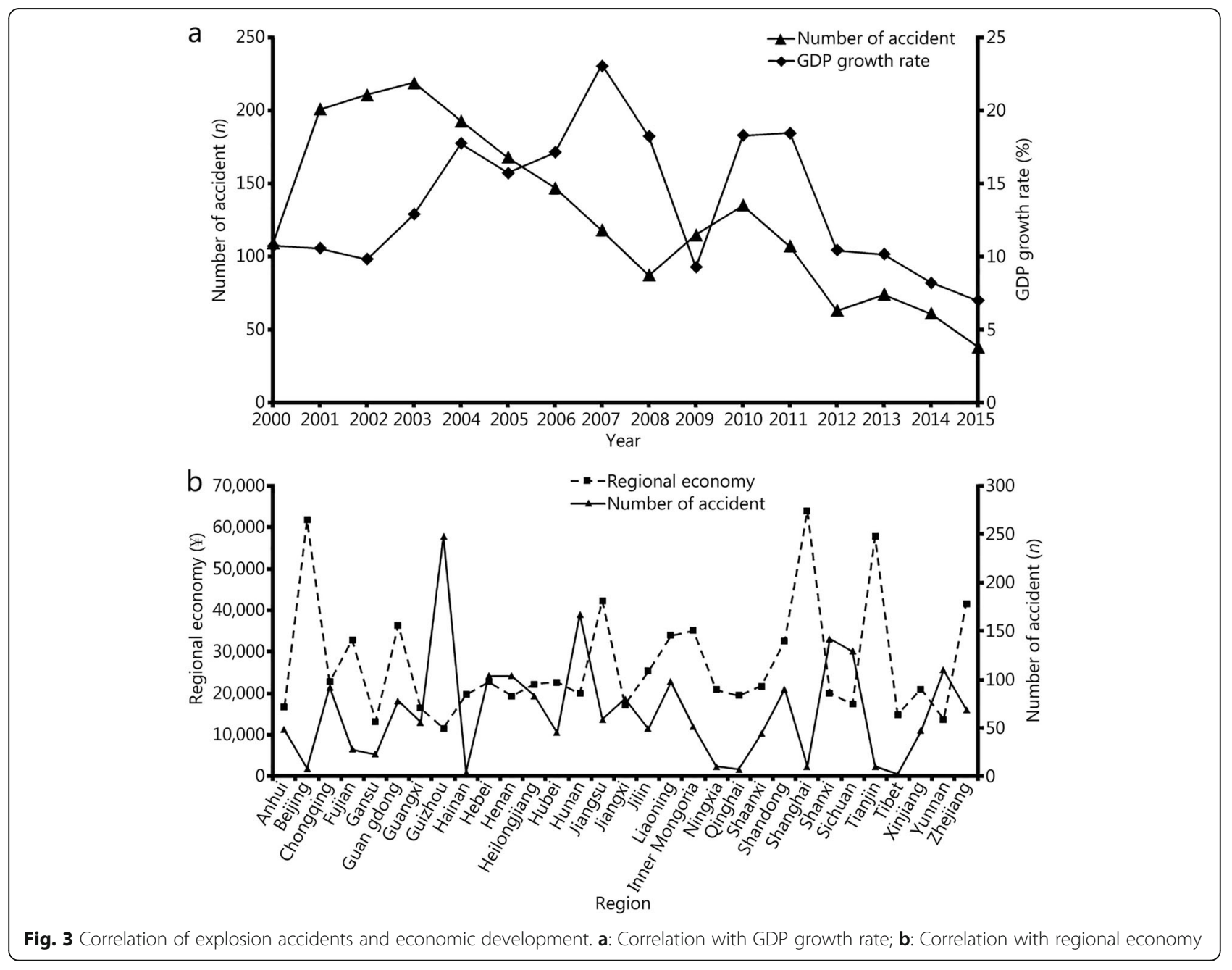


were coal mine gas, pyrotechnics, ignitable gas and explosive chemical compound among the 11 material subtypes (Table 3 ).

\section{Discussion}

The current study identified a total of 2098 explosions, with 29,579 casualties during a period from January 1, 2000 and April 30, 2017. On average, one explosion accident happened every 2.8 days; nearly five people suffered from blast injury every day. The mean number of casualties per explosion accident was fourteen. The mean number of deaths in the extraordinarily major accidents was 58.0 per accident.

In general, civilians are poorly prepared to handle the severe emotional, logistical and medical burden of a sudden, large influx of casualties [24]. Upon a catastrophe, medical facilities must be prepared to manage massive numbers of severely injured patients [25]. The current study indicated a decline in morbidity and mortality in civilian explosion accidents from 2000 to 2017 in China, but extraordinarily major accidents remain a dire challenge for the emergency rescue teams. Large number of patients must be triaged and treated in the chaotic circumstances within a short period of time. Decreasing number of in missing victims during the study period in the current study may be attributed to improvements in search strategies and equipment as well as the increasing use of DNA identification [26].

Explosives accidents tended to occur at 9:00-11:00 am or 4:00-6:00 pm during the day. These times generally relate to busy activity by majority of the facility personnel. The fact that explosion accidents were most frequent in the fourth quarter of every year is consistent with the high volume of business production towards the end of year. The use of heating systems might also have contributed to the high incidence in the fourth quarter of the year. Thus, we recommend that early warning systems be installed at these specific time intervals to alert for the high risk of explosions.

Explosion accidents and mass casualties are most frequent in coal-producing provinces. Resolving this issue clearly depends on alternative energy sources other than coal [27-29]. Since nearly half of explosives accidents resulted from coal mine gas, most of the victims in these coal mine explosions sustain serious blast injuries [30].

As a developing country, the principal risk factors in China of explosion accidents remain industrial causes. The current study suggested that, in addition to advanced search-and-rescue systems, emphasis must be placed in addressing un-planned expansion of industrial production [31, 32]. At the level of individualized protection, coal mine-related personnel should be provided with equipment that absorb blast waves [33-35] in addition to bulletproof materials [36] to minimize blast injury.

There are several limitations in the current study. First, we do not know the extent of non-reporting in the SAWS database despite of its mandatory nature. The second limitation is the lack of information on long-term physical, psychological and social impact of the explosions on survivors. It is also necessary to analyze the causes of death, injury types and emergency rescue and medical response effort in more details in future studies.

\section{Conclusions}

In summary, civilian explosion is unacceptably common, with high casualties in China despite of a decline in the past few years. The overall strategy of injury relief is effective, but more individualized and universal protective measures are needed.

Table 3 The number of explosions by explosion charges

\begin{tabular}{lllllllll}
\hline Material subtype & 2010 & 2011 & 2012 & 2013 & 2014 & 2015 & 2016 & Total $[n(\%)]$ \\
\hline Coal mine gas & 33 & 28 & 14 & 20 & 14 & 6 & 11 & $126(24.5)$ \\
Pyrotechnics & 30 & 22 & 7 & 16 & 6 & 5 & 7 & $93(18.1)$ \\
Ignitable gas & 16 & 12 & 14 & 9 & 14 & 11 & 2 & $78(15.2)$ \\
Explosive chemical compound & 15 & 16 & 6 & 7 & 7 & 8 & 7 & $66(12.8)$ \\
Other sealed equipment & 6 & 7 & 11 & 7 & 2 & 1 & 2 & $36(7.0)$ \\
Explosive blasting agent & 12 & 5 & 5 & 6 & 6 & 0 & 1 & $35(6.8)$ \\
Ignitable liquid & 10 & 2 & 1 & 4 & 6 & 1 & 1 & $25(4.9)$ \\
Ignitable solid & 5 & 5 & 1 & 1 & 3 & 2 & 4 & $21(4.1)$ \\
Boiler & 3 & 5 & 3 & 1 & 0 & 0 & 4 & $16(3.1)$ \\
Other (Not identified) & 2 & 4 & 0 & 2 & 2 & 0 & 2 & $12(2.3)$ \\
Black powder/black powder Substitutes & 1 & 0 & 0 & 0 & 1 & 4 & 0 & $6(1.2)$ \\
\hline
\end{tabular}




\section{Supplementary information}

Supplementary information accompanies this paper at https://doi.org/10. 1186/s40779-020-00257-5.

Additional file 1: Table S1. Casualty by explosion accidents grade $[n(\%)]$.

Additional file 2: Table S2. Correlation analysis of explosion accidents and regional population and economy.

\section{Abbreviations}

GDP: Gross domestic product; SAWS: State Administration of Work Safety STROBE: The Strengthening the Reporting of Observational Studies in Epidemiology

\section{Acknowledgements}

The authors thank Tianjin Fifth Central Hospital, Affiliated Hospital of Logistic University of the Chinese People's Armed Police Force (PAP), Tianjin Medical University General Hospital, Tianjin First Central Hospital, Tianjin Taida Hospital for the assistance of data collection in "8.12" giant explosion in Tianjin harbor. We appreciate the help from Professor Xiao-Bing Fu (Wound Healing and Cell Biology Laboratory, Burns Institute, The First Affiliated Hospital, Chinese PLA General Hospital), Professor Bao-Guo Jiang (Department of Traumatology and Orthopedics, Peking University People's Hospital), Professor Yue-Sheng Huang (Burn Institute, Southwestern Hospital, the Third Military Medical University), Professor Lian-Yang Zhang, Professor Jian-Min Wang and Dr. Liang Zhang (Research Institute of Surgery, Daping Hospital, the Third Military Medical University).

\section{Authors' contributions}

$C Y, J X J$ and ZGW designed research; XW, JD, CY, and ZZ performed research; CY drafted the manuscript. CY takes the responsibility for the integrity of the data and the accuracy of the data analysis. All authors read and approved the final manuscript.

\section{Funding}

This work was supported by Major State Research Projects (613307), Army Medical Center Talent Innovation Ability Training Program (2019CXJSB007), Thirteenth Five-Year "Double" Construction Research and Innovation Project of PLA (2019), and Medical Research Funding of PLA (ASW14C003).

\section{Availability of data and materials}

All authors had full access to all the data in the study.

\section{Ethics approval and consent to participate}

This study was approved by the Institutional Review Board and the Medical Ethics Committee of Daping Hospital, the Army Medical University, China (HUUWEC2017017).

\section{Consent for publication}

Not applicable.

\section{Competing interests}

The authors declare that they have no conflicts of interest.

\section{Author details}

'State Key Laboratory of Trauma, Burn and Combined Injury, Research Institute of Surgery, Daping Hospital, Army Medical University, Chongqing 400042, China. ${ }^{2}$ Department of Emergency, the Second Affiliated Hospital of Medical College in Zhejiang University, Hangzhou 310009, China. ${ }^{3}$ Applied Mechanics Laboratory, School of Aerospace, Tsinghua University, Beijing 100084, China.

Received: 28 July 2019 Accepted: 18 May 2020

Published online: 11 June 2020

\section{References}

1. Schonfeld DJ. The role of pediatricians in the face of increasing domestic terrorism threats. JAMA Pediatr. 2016;170(4):311-2.
2. Rozenfeld M, Givon A, Shenhar G, Renert L, Peleg K. A new paradigm of injuries from terrorist explosions as a function of explosion setting type. Ann Surg. 2016;263(6):1228-34.

3. Yu M, Lv Q, Ding H, Zeng X, Cao J, Liu J, et al. Evaluation of blast injury patients from the 2015 Tianjin explosions in China. Burns. 2016;42(5):1133-40.

4. Yang C, Jiang JX, Du J, Wang HY, Gao J, ZL L, et al. Vigilance and enlightenment from diagnosis and therapy of blast injury in the "8.12" giant explosion in Tianjin harbor. Chin J Diagnost. 2016;4(1):7-10.

5. Ritenour AE, Blackbourne LH, Kelly JF, McLaughlin DF, Pearse LA, Holcomb JB, et al. Incidence of primary blast injury in US military overseas contingency operations: a retrospective study. Ann Surg. 2010;251(6):1140-4.

6. Sheridan RL, Shumaker PR, King DR, Wright CD, Itani KM, Cancio LC. Case records of the Massachusetts General Hospital. Case 15-2014. A man in the military who was injured by an improvised explosive device in Afghanistan. N Engl J Med. 2014;370(20):1931-40.

7. Wolf SJ, Bebarta VS, Bonnett CJ, Pons PT, Cantrill SV. Blast injuries. Lancet. 2009:374(9687):405-15.

8. Ropper A. Brain injuries from blasts. N Engl J Med. 2011;364(22):2156-7.

9. Jani N, Falvo MJ, Sotolongo A, Osinubi OY, Tseng CL, Rowneki M, et al. Blast injury and cardiopulmonary symptoms in U.S. veterans: analysis of a national registry. Ann Intern Med. 2017:167(10):753-5.

10. Ashkenazi I, Olsha O, Turegano-Fuentes F, Alfici R. Tympanic membrane perforation impact on severity of injury and resource use in victims of explosion. Eur J Trauma Emerg S. 2017;43(5):623-6.

11. Yang C, Gao J, Wang HY, Liu Q, Xu MH, Wang ZG, et al. Effects of hypothalamus destruction on the level of plasma corticosterone after blast injury and its relation to interleukin-6 in rats. Cytokine. 2011;54(1):29-35.

12. van Rijswijk JB, Dubach P. Binaural tympanic-membrane perforations after blast injury. N Engl J Med. 2017;376(19):e41.

13. Aldag M, Armstrong RC, Bandak F, Bellgowan PSF, Bentley T, Biggerstaff S, et al. The biological basis of chronic traumatic encephalopathy following blast injury: a literature review. J Neurotrauma. 2017;34(S1):S26-43.

14. Yang C, Jiang JX, Du J, Wang HY, Gao J, Liu ZL, et al. Thinking of the precision diagnosis and therapy of pulmonary blast injury from the view of translational medicine. Chin J Diagnost. 2016;4(1):4-6.

15. Aharonson-Daniel $L$, Klein $Y$, Peleg K. Itg. Suicide bombers form a new injury profile. Ann Surg. 2006;244(6):1018-23.

16. Born CT. Blast trauma: the fourth weapon of mass destruction. Scand J Surg. 2005;94(4):279-85

17. Yang C, Jiang JX, Du J, Wang HY. L ZL, Zhuang Z, et al. some problems deserved to be paid close attention in the diagnosis and therapy of blast injury. Chin J Diagnost. 2016:4(1):23-5.

18. Kauvar DS, Wolf SE, Wade CE, Cancio LC, Renz EM, Holcomb JB. Burns sustained in combat explosions in operations Iraqi and enduring freedom (OIF/OEF explosion burns). Burns. 2006;32(7):853-7.

19. McAlister CN, Marble AE, Murray TJ. The 1917 Halifax explosion: the first coordinated local civilian medical response to disaster in Canada. Can J Surg. 2017;60(6):372-4.

20. Haug CJ. Report from Paris. N Engl J Med. 2015;373(27):2589-93.

21. Gates JD, Arabian S, Biddinger P, Blansfield J, Burke P, Chung S, et al. The initial response to the Boston marathon bombing: lessons learned to prepare for the next disaster. Ann Surg. 2014;260(6):960-6.

22. Dadgar I, Norstrom T. Short-term and long-term effects of GDP on traffic deaths in 18 OECD countries, 1960-2011. J Epidemiol Community Health. 2017:71(2):146-53.

23. Bougueroua M, Carnis L. Economic development, mobility and traffic accidents in Algeria. Accid Anal Prev. 2016:92:168-74.

24. Sharma BR. Disaster management following explosion. Am J Disaster Med 2008;3(2):113-9.

25. Yang C, Wang HY, Zhong HJ, Zhou L, Jiang DM, Du DY, et al. The epidemiological analyses of trauma patients in Chongqing teaching hospitals following the Wenchuan earthquake. Injury. 2009;40(5):488-92.

26. Yang C, Gao J, Du J, Wang H, Jiang J, Wang Z. Understanding the outcome in the chinese changjiang disaster in 2015: a retrospective study. J Emerg Med. 2017:52(2):197-204.

27. Li J, Kong Y, Wang S. Clinical characteristics of burn caused by coal mine explosion. Chin J Burns. 1998;14(6):436-8.

28. Orecka B, Sikora L, Misiolek M, Fira R, Miskiewicz-Orczyk K, Paluch Z, et al. The quality of voice in coal-miners after burn/inhalation injury due to methane explosion. Otolaryngol Pol. 2012;66(2):102-8. 
29. Walker B Jr, Adenuga B, Mouton C. The relevance of occupational medicine to primary care in the 21st century. J Natl Med Assoc. 2011;103(4):306-12.

30. Roberts L, Bailes J, Dedhia H, Zikos A, Singh A, McDowell D, et al. Surviving a mine explosion. J Am Coll Surg. 2008;207(2):276-83.

31. Zhao J, Gao J, Zhao F, Liu Y. A Search-and-rescue robot system for remotely sensing the underground coal mine environment. Sensors (Basel). 2017; 17(10):E2426.

32. Yang C, Jiang JX, Zhuang Z, Wang ZG. Transformation research of pulmonary blast injury - history, current situation and challenges. Pract J Med Pharm. 2019;36(1):1-5.

33. Chen XL, Wang YJ, Wang CR, Li SS. Gunpowder explosion burns in fireworks factory: causes of death and management. Burns. 2002;28(7):655-8.

34. Chen H, Li XP, Chen YY, Huang GL. Wave propagation and absorption of sandwich beams containing interior dissipative multi-resonators. Ultrasonics. 2017:76:99-108.

35. Yang C, Jiang JX, Du J, Wang HY, Gao J, ZL L, et al. Thinking of the defensive strategy on the non-martial explosion on account of the diagnosis and therapy of blast injury. Chin J Diagnost. 2016;4(1):10-2.

36. Lee JK. Bulletproof silk: observations of Dr George E. good fellow, the gunfighter's surgeon. J Am Osteopath Assoc. 2016;116(11):e97-8.

Ready to submit your research? Choose BMC and benefit from:

- fast, convenient online submission

- thorough peer review by experienced researchers in your field

- rapid publication on acceptance

- support for research data, including large and complex data types

- gold Open Access which fosters wider collaboration and increased citations

- maximum visibility for your research: over $100 \mathrm{M}$ website views per year

At $\mathrm{BMC}$, research is always in progress.

Learn more biomedcentral.com/submissions 